\title{
Composição química e qualidade de conservação de silagens de grãos de milho (Zea mays L.) com diferentes níveis de grãos de soja (Glycine max Merril)
}

\author{
Chemical composition and quality of conservation of corn \\ (Zea mays L.) grain silages with differents levels of soy grains \\ (Glycine max Merril)
}

\author{
Clóves Cabreira Jobim ${ }^{1 *}$, Moyses Calixto Junior ${ }^{2}$, \\ Valter Harry Bumbieris Júnior ${ }^{3}$, Fábio Cortez Leite de Oliveira ${ }^{4}$
}

\section{Resumo}

O objetivo deste trabalho foi avaliar os efeitos de diferentes porcentagens de grãos de soja crus, adicionados aos grãos de milho, sobre as características de fermentação e composição química das silagens. Os tratamentos testados foram, silagem de grãos de milho com inclusão de $0,10,20,30,40 \%$ de grãos de soja crus. Foram utilizados silos experimentais com capacidade para aproximadamente 12 $\mathrm{kg}$ de silagem, sendo que esses permaneceram vedados por um período de 12 meses, quando foram abertos para amostragens e análises químicas. O delineamento experimental empregado foi inteiramente casualizado, com três repetições por tratamento. A adição de grãos de soja proporcionou aumento nos teores dos nutrientes (MM, PB, EE) das silagens, sem interferir na qualidade de conservação das mesmas.

Palavras-chave: Aditivos, matéria seca, nitrogênio amoniacal, proteína bruta

\begin{abstract}
It was aimed to assess the effects of different percentages of soy bean grain, added to corn grain, on fermentation characteristic and chemical composition of silages. The treatments tested were: corn grain silage with $0,10,20,30,40 \%$ different levels of soy bean grain. Experimental silos with approximate $12 \mathrm{~kg}$ of capacity were used. They were sealed for 12 months and after that they were opened to get samples for chemical analysis. It was used a completely randomized design, with three replicates per treatment. The addition of raw soy bean grain, increased the content of nutrients (Ash, CP and EE) of silages, without interfering the fermentation quality of the silage.
\end{abstract}

Key words: Addictive, ammoniacal nitrogen, crude protein, dry matter

${ }^{1}$ Zootecnista, Docente, Professor Associado - Departamento de Zootecnia/DZO - Universidade Estadual de Maringá/UEM. E-mail: ccjobim@uem.br

${ }^{2}$ Zootecnista, Doutorando em Zootecnia - Departamento de Zootecnia/DZO - Universidade Estadual de Maringá/UEM. E-mail: m.cjunior@bol.com.br

${ }^{3}$ Zootecnista, Docente, Professor Adjunto - Departamento de Zootecnia/DZO - Universidade Estadual de Londrina/UEL. E-mail: jrbumbieris@uel.br

${ }^{4}$ Zootecnista - Mestrando em Zootecnia - Departamento de Zootecnia/DZO - Universidade Estadual de Maringá/UEM. E-mail: oliveirafcl@hotmail.com

* Autor para correspondência 


\section{Introdução}

A alimentação animal é cada vez mais discutida no meio produtivo e científico, em face aos custos dos insumos, principalmente os alimentos concentrados. Diante disso, a utilização de tecnologias que permitam eficiência e economicidade na produção animal são imprescindíveis.

Nesse sentido, o uso de silagem de grãos de milho é uma importante alternativa tecnológica para a formulação de concentrados (JOBIM; BRANCO, SANTOS, 2003). Apesar do milho em grão ser largamente utilizado na alimentação animal, o uso de grãos ensilados no Brasil, ainda é uma tecnologia em expansão.

A ensilagem dos grãos pode contribuir para minimizar as perdas, além de permitir um sistema de armazenagem mais simples e econômico (JOBIM; REIS; RODRIGUES, 1997; ÍTAVO et al., 2006). Além de proporcionar diminuição de perdas qualitativas e quantitativas, em função do ataque de insetos e de ratos, também a colheita do milho para ensilar proporciona antecipação na retirada da cultura da lavoura com grandes benefícios num esquema de rotação de culturas, além de reduzir significativamente as perdas no campo (JOBIM; CECATO, CANTO, 2001).

A qualidade de silagem de grãos de milho pode ter valor nutricional melhorado com adição de grãos de oleaginosas. Assim, a soja em grãos pode ser uma alternativa para esse propósito, pois pode estar disponível a preços mais acessíveis que o próprio farelo, especialmente se for colhida na propriedade, além de apresentar inquestionável valor nutricional.

O objetivo desse trabalho foi avaliar os efeitos da inclusão de diferentes porcentagens de grãos de soja crus nas silagens de grãos de milho, sobre a composição química e conservação das silagens.

\section{Material e Métodos}

O experimento foi desenvolvido na Fazenda Experimental deIguatemienoLaboratório deAnálise de Alimentos e Nutrição Animal do Departamento de Zootecnia da Universidade Estadual de Maringá. Os tratamentos testados foram silagens de grãos de milho com inclusão de níveis crescentes de grãos de soja crus, ficando assim definidos: $\mathrm{T}_{1}=$ grãos de milho; $\mathrm{T}_{2}=$ grãos de milho $+10 \%$ de grãos de soja; $\mathrm{T}_{3}=$ grãos de milho $+20 \%$ de grãos de soja $_{;} \mathrm{T}_{4}=$ grãos de milho $+30 \%$ de grãos de soja; $\mathrm{T}_{5}=$ grãos de milho $+40 \%$ de grãos de soja.

O milho, variedade Dina 140, plantio safrinha, foi colhido após atingir o ponto adequado para ensilagem dos grãos (em torno de $70 \%$ de MS). Os grãos foram triturados, sendo que no momento da moagem, foram incluídas as porcentagens de grãos de soja referentes a cada tratamento (relação kg/kg), para obter-se melhor homogeneização da mistura.

Depois de triturado, o material foi ensilado em silos experimentais de PVC ( $20 \mathrm{~cm}$ de diâmetro com $40 \mathrm{~cm}$ de altura) com capacidade de armazenagem de aproximadamente $12 \mathrm{~kg}$ de silagem. Os silos permaneceram vedados por um período de 12 meses, sendo então abertos para posteriores análises químicas.

No momento da ensilagem foram realizadas amostragens, para determinação dos valores de $\mathrm{pH}$, teor de matéria seca (MS) e composição química dos grãos. Quando da abertura dos silos, foram feitas novas amostragens para avaliação da composição química das silagens. Os teores de matéria seca (MS), proteína bruta $(\mathrm{PB})$, extrato etéreo (EE), matéria mineral (MM), foram obtidos segundo AOAC (1990). A determinação da fibra em detergente neutro (FDN), foi obtida de acordo com Van Soest e Robertson (1985), e os valores de $\mathrm{pH}$ e nitrogênio amoniacal $\left(\mathrm{N}-\mathrm{NH}_{3}\right)$ segundo Phillip e Fellner (1992).

O delineamento experimental utilizado foi inteiramente casualizado com três repetições para cada tratamento. Os dados foram avaliados por meio de análises de variância e regressão utilizando-se o Sistema de Análises Estatísticas - SAEG, (UFV, 1997), seguindo-se o modelo estatístico: 


$$
\mathrm{Y}_{\mathrm{ij}}=\mu+\mathrm{Ns}_{\mathrm{i}}+\mathrm{e}_{\mathrm{ij}}
$$

Onde:

$\mathrm{Y}_{\mathrm{ij}}=$ observação referente a cada tratamento, $\mu=$ constante geral,

$\mathrm{Ns}_{\mathrm{i}}=$ efeito do tratamento (nível de soja) i, $\mathrm{e}_{\mathrm{ij}}=$ erro aleatório associado a cada variável.

\section{Resultados e Discussão}

Houve aumento $(\mathrm{P}<0,05)$ na porcentagem de matéria seca com a inclusão de grãos de soja antes e após a ensilagem (Figura 1). Constatou-se que a adição de grãos de soja resultou em aumento linear nos teores de MS dos grãos antes da ensilagem, apresentando valor mínimo de $65 \%$ de MS na ausência de grãos de soja e máximo de $75 \%$ com a adição de 40\% de grãos de soja.

Entretanto, após a ensilagem, a adição de grãos de soja apresentou comportamento quadrático para os teores de MS, apresentando valor mínimo de $66 \%$ e máximo de $74 \%$ com a adição de 0 e $40 \%$ de grãos de soja, respectivamente. Esse comportamento pode ser explicado pelo maior teor de matéria seca dos grãos de soja (73\%) em relação aos grãos de milho (67\%), no momento da ensilagem.

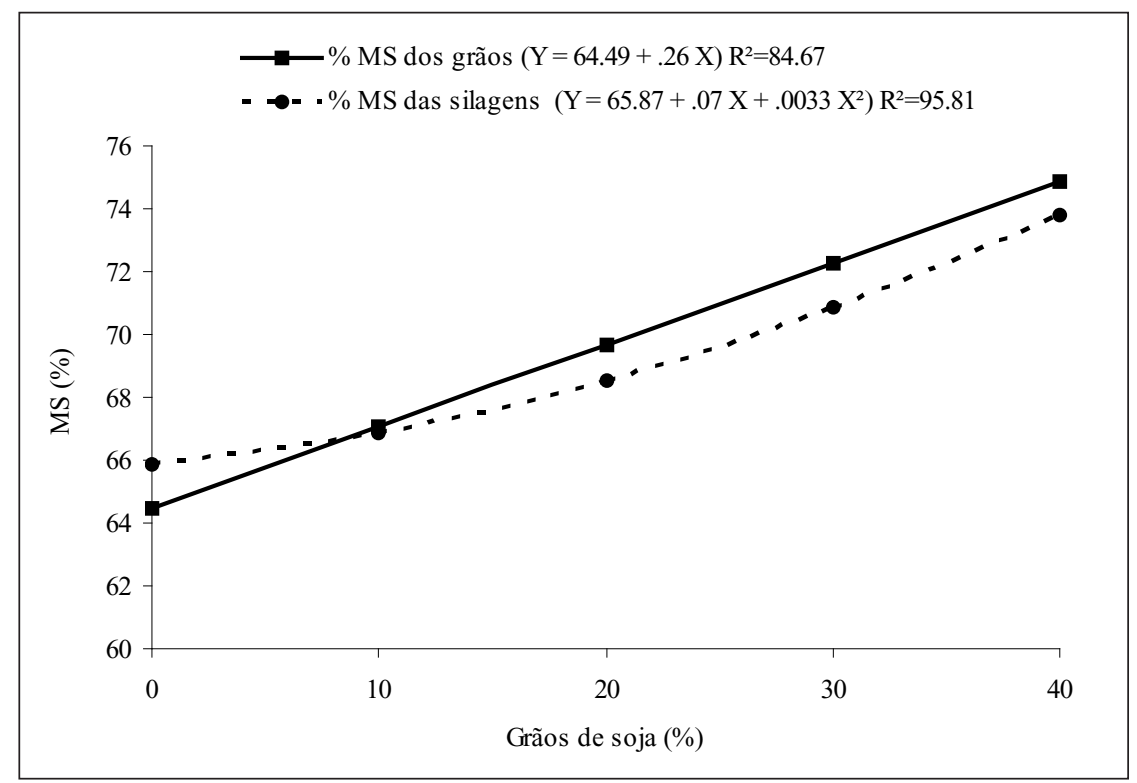

Figura 1. Teores de matéria seca (MS) em grãos de milho com diferentes percentagens de grãos de soja antes e após a ensilagem.

Normalmente a silagem de grãos de milho apresenta teores de matéria seca entre 64 e 70\% (JOBIM; REIS; RODRIGUES, 1997; REIS et al.; 2001; SANTOS et al., 2002). Esses valores são obtidos no estádio de maturação fisiológica completa, momento da colheita mais adequado para obter-se equilíbrio na qualidade dos grãos e boa qualidade de fermentação no silo. Apesar de, nos tratamentos com maior inclusão de grãos de soja, o teor de MS ser maior em relação às recomendações normalmente sugeridas na literatura, esses teores não influenciaram negativamente a conservação dessas silagens.

Na Figura 2, observa-se aumento linear $(\mathrm{P}<0,05)$ no teor de matéria mineral $(\mathrm{MM})$ à medida que os grãos de soja foram sendo adicionados ao milho na ensilagem. Constatou-se que a silagem apresentou maior teor de MM a partir da adição de $10 \%$ de grãos 
de soja em relação aos grãos antes da ensilagem. Esse comportamento pode ser explicado pelas perdas de outros componentes da MS (carboidratos solúveis, proteína) que normalmente ocorrem no processo de ensilagem, resultando em aumento na concentração da fração mineral.
Segundo Ashbell (1995), a elevação no teor de cinza é indicativo de perdas, pois, quando à fermentação inadequada, ocorrem perdas de material orgânico, aumentando a participação relativa da cinza ( material mineral) na MS.

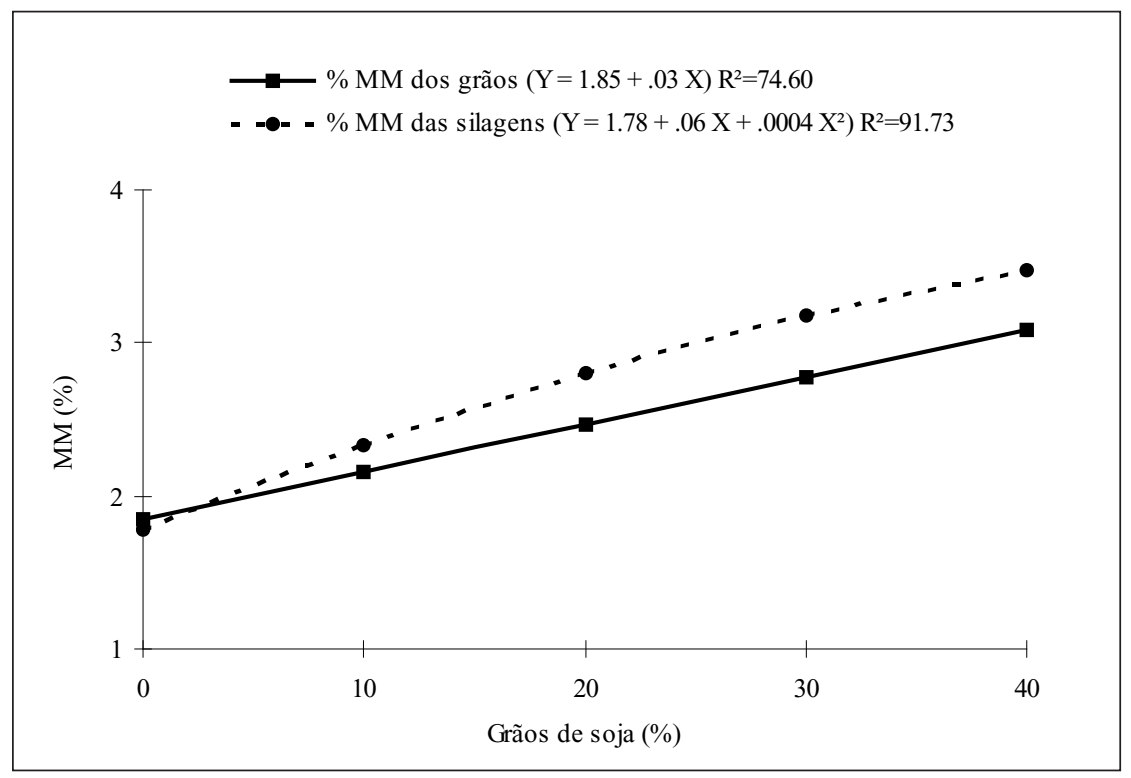

Figura 2. Teores de matéria mineral (MM) em grãos de milho com diferentes percentagens de grãos de soja antes e após a ensilagem.

No presente estudo a silagem de grãos de milho sem adição de grãos de soja apresentou teores de MM equivalentes aos encontrados por Passini et al. (2002) e superiores aos valores obtidos por Reis et al. (2001) que registraram 0,9\% de MM. Isso pode ser atribuído às diferenças do híbrido de milho utilizado e da magnitude das perdas de compostos solúveis no processo de ensilagem.

Os teores de proteína bruta (PB) apresentaram comportamento linear $(\mathrm{P}<0,05)$ com o aumento da inclusão de grãos de soja (Figura 3). A adição de $40 \%$ de grãos de soja resultou em uma silagem com $26 \%$ de proteína bruta, enquanto a silagem de grãos de milho puro apresentou 9,5\% de proteína bruta. Os valores de proteína bruta foram maiores na silagem em relação aos grãos antes de ensilar, a partir da adição de $20 \%$ de grãos de soja. Esse comportamento pode ser atribuído ao efeito de concentração dos constituintes da MS, em resultado da dinâmica de fermentação durante o processo de ensilagem. 


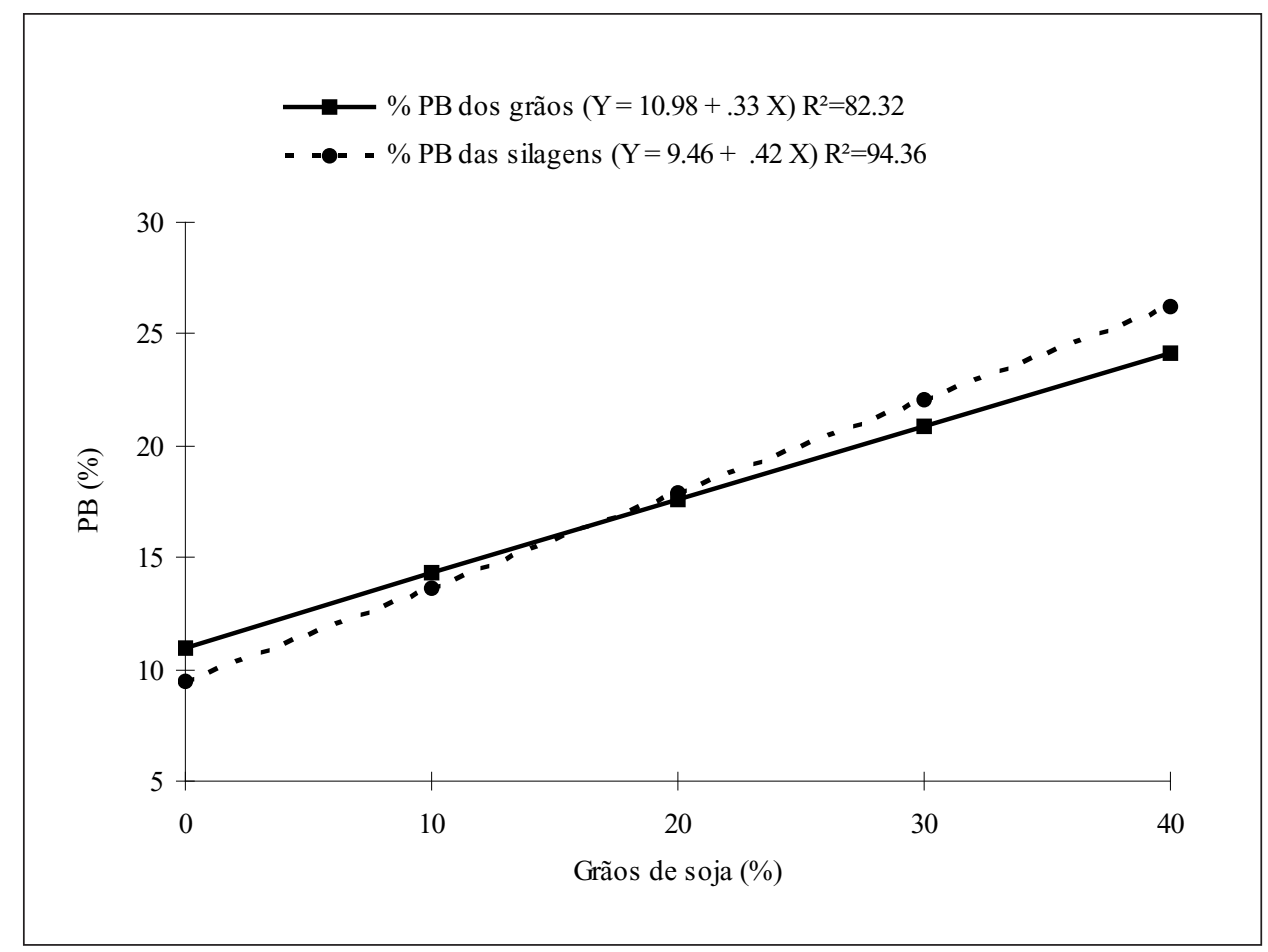

Figura 3. Teores de proteína bruta (PB) em grãos de milho com diferentes porcentagens de grãos de soja antes e após a ensilagem.

Normalmente, silagens de grãos de milho apresentam valores entre 9,0 e $11 \%$ de proteína bruta (JOBIM; REIS; RODRIGUES, 1997; REIS et al.; 2001; SANTOS et al., 2002). Com a adição de grãos de soja no momento da ensilagem é possível obter uma silagem com valores protéicos que, associados ao volumoso, podem satisfazer as exigências dos ruminantes para níveis de produção satisfatórios, em virtude do maior teor protéico desses grãos em relação aos de milho. Haja visto, que as exigências de proteína bruta para bovinos em terminação é de $12,5 \%$, com base na matéria seca (NRC, 1996).
O teor de fibra em detergente neutro na silagem apresentou aumento linear $(\mathrm{P}<0,05)$ com a adição de grãos de soja (Figura 4), com valores entre 6,06 e 13,6 \% de FDN nas silagens de grãos de milho puro e grãos de milho com $40 \%$ de grãos de soja, respectivamente.

Os teores de FDN encontrados para as silagens de milho, são variáveis em função da presença de sabugo e do próprio cultivar utilizado (JOBIM; REIS; RODRIGUES, 1997). Porém, consta na literatura valores que variam entre 9,0 e $16,0 \%$ para a silagem de grãos de milho (PASSINI et al., 2002; REIS et al., 2001). 


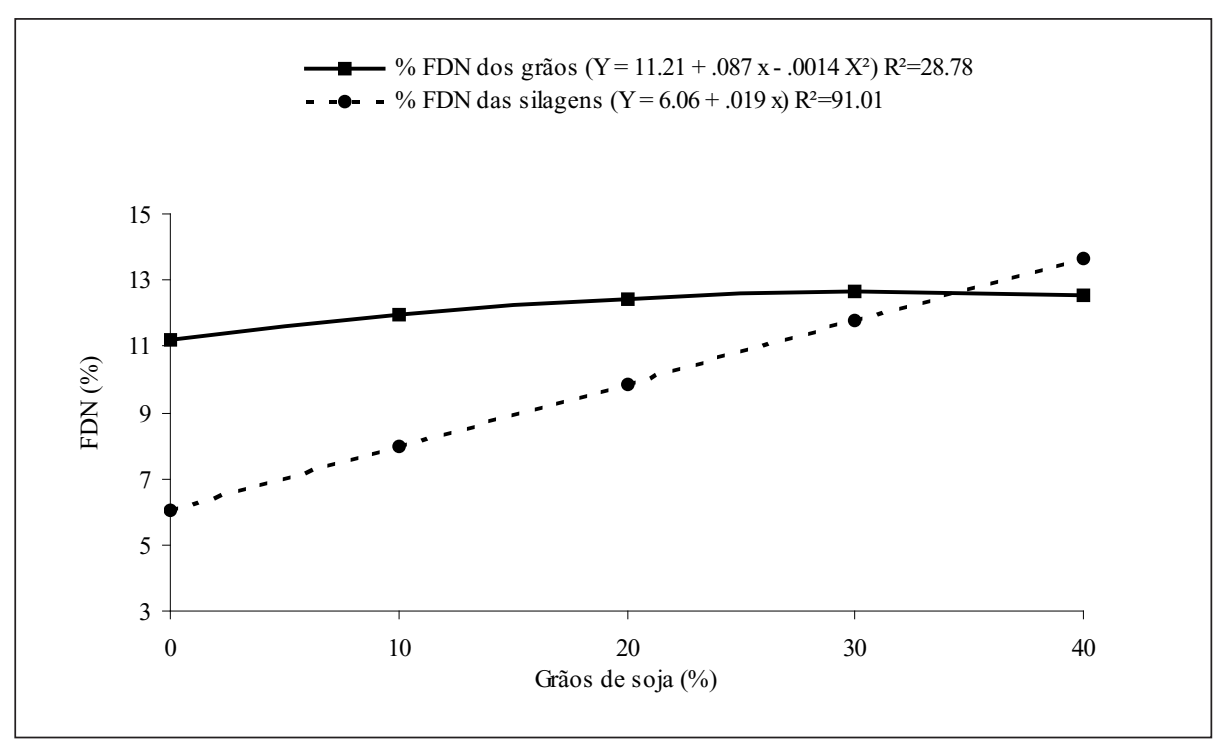

Figura 4. Concentração de fibra em detergente neutro (FDN) em grãos de milho com diferentes percentagens de grãos de soja antes e após a ensilagem.

O teor de FDN nos grãos antes da ensilagem apresentou pequena variação com valor médio de 12,17\%. Já a fração FDN das silagens mostrou crescimento linear com adição dos grãos de soja. A diferença observada nos valores de FDN antes e após a ensilagem não é explicada, onde normalmente há aumento nos teores de FDN de silagens, em relação ao material fresco, por efeito de concentração dos componentes estruturais.

Na Figura 5 observa-se a variação $(\mathrm{P}<0,05)$ da porcentagem de extrato etéreo (6,0 para 13,5\%) na silagem de grãos de milho isento da adição de grãos de soja e com a inclusão de $40 \%$ desse grão. Esse aumento gradativo com aumento da porcentagem de grãos de soja, deve-se ao maior teor de extrato etéreo presente nesse grão em relação ao milho. Reis et al. (2001) também encontraram valores semelhantes $(4,8)$ aos observados, nesse estudo, para a silagem de grãos de milho.

Os teores de extrato etéreo foram semelhantes entre os materiais antes e após a ensilagem, para as mesmas quantidades de soja adicionada. Isto indica que houve pouca variação no teor de extrato etéreo durante a armazenagem, evidenciando poucas perdas desse nutriente na ensilagem desses grãos. O comportamento linear crescente do teor de EE nas silagens é atribuído ao alto teor de óleo da soja, normalmente entre $18-19 \%$.

Na Figura 6, são apresentados os valores de $\mathrm{pH}$ para as silagens de grãos úmidos de milho sem e com a inclusão de diferentes porcentagens grãos de soja. Os valores de $\mathrm{pH}$ apresentaram comportamento quadrático com a adição de maiores quantidades de grãos de soja. $\mathrm{O}$ pH da silagem de grãos de milho foi de 3,95 e aumentou para 4,62 com a adição de $40 \%$ de grãos de soja, fato esse já esperado, em virtude da maior quantidade de compostos protéicos presentes com a inclusão de grãos de soja, os quais têm influência negativa no abaixamento do $\mathrm{pH}$ das silagens. Valores aproximados ao desse estudo foram observados também por Ítavo et al. (2006), com valores médios de 3,97 para silagens de grãos de milho isento da aplicação de aditivos. 


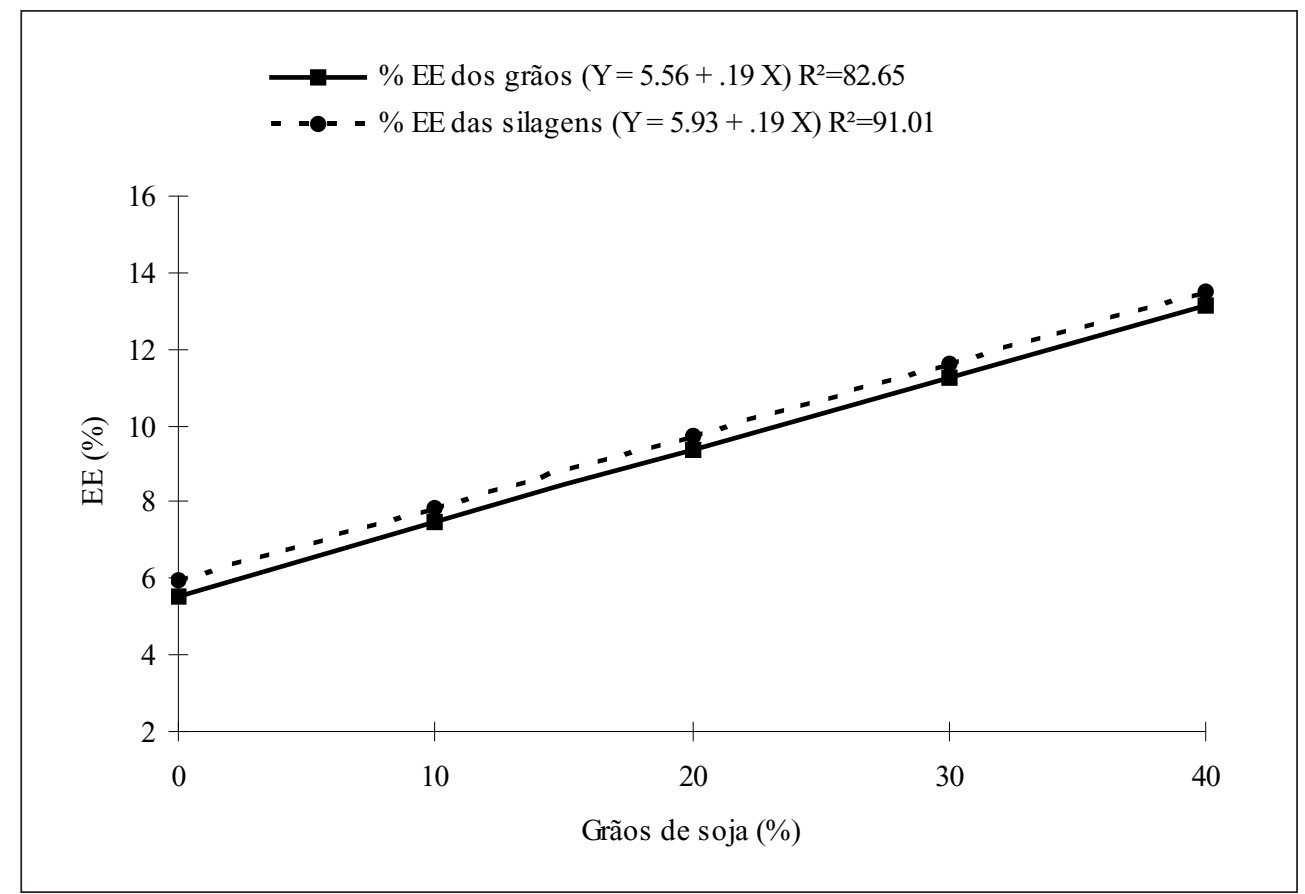

Figura 5. Teores de extrato etéreo (EE) em grãos de milho com diferentes percentagens de grãos de soja antes e após a ensilagem.

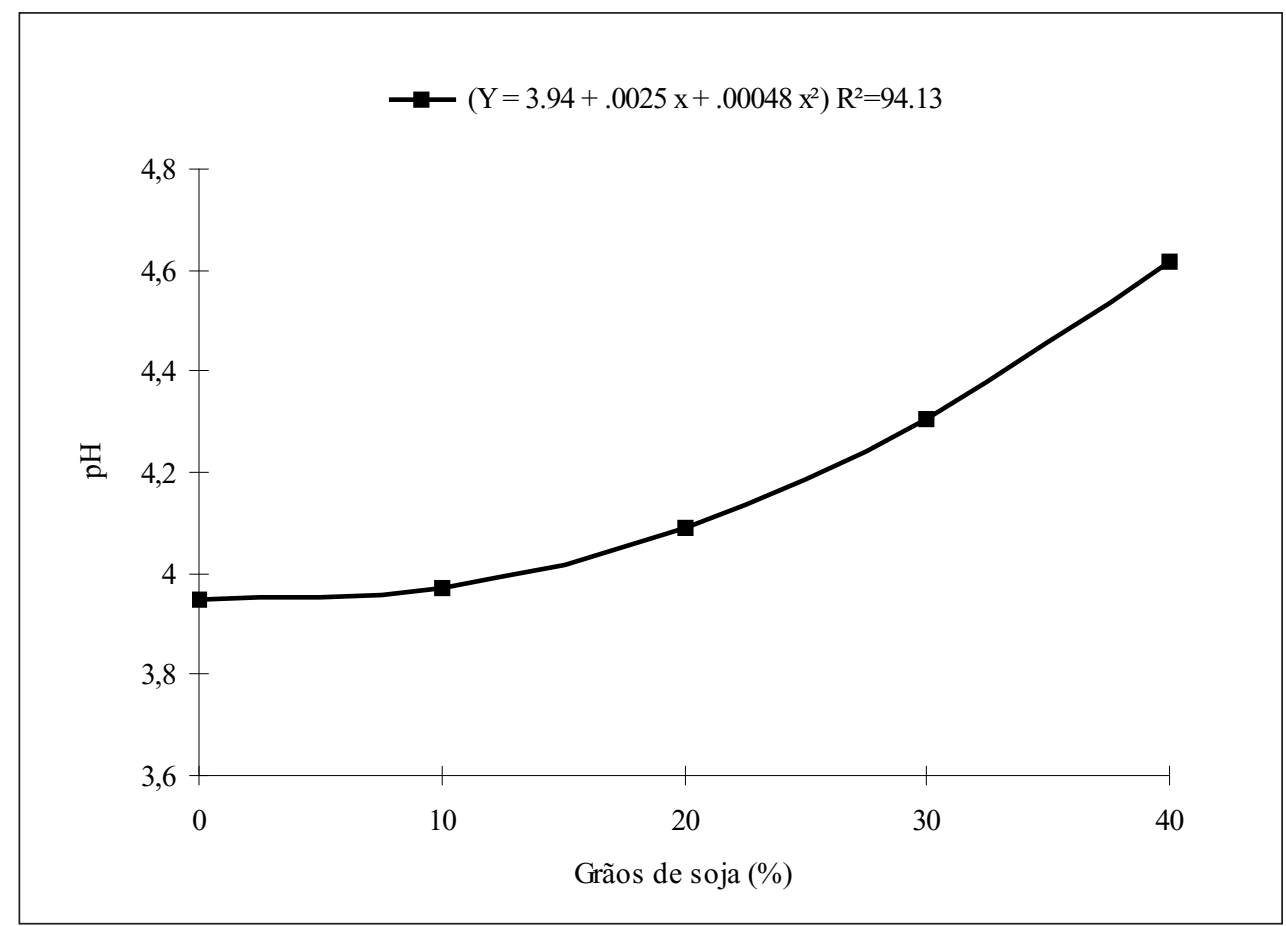

Figura 6. Valores de pH em silagens de grãos de milho com diferentes percentagens de grãos de soja. 
Constatou-se que, mesmo para as silagens com pH mais elevado, não houve efeito sobre as perdas de material deteriorado na superfície dos silos durante a armazenagem. Todas as silagens apresentaram perdas superficiais reduzidas, mesmo considerando o período de armazenagem de 12 meses.

$\mathrm{O}$ nitrogênio amoniacal $\left(\mathrm{N}-\mathrm{NH}_{3} / \mathrm{N}_{\text {TOTAL }}\right)$ das silagens variou com a inclusão de grãos de soja, porém, não houve efeito significativo entre tratamentos, apresentando resultados semelhantes para todas as silagens (Figura 7).

Os valores para nitrogênio amoniacal obtidos, nesse estudo, foram semelhantes aos registrados por Jobim; Reis e Rodrigues (1997) e Ítavo et al.
(2006), que observaram valores de 1,05 e 1,32\% respectivamente, porém sem a inclusão de grãos de soja. Os baixos valores de nitrogênio amoniacal observados em silagem de grãos de milho revelaram que há baixa atividade de enzimas proteolíticas e de microrganismo com ação proteolítica. Os microrganismos com maior atividade proteolítica em silagens são os clostrideos. No entanto, devido ao alto teor de matéria seca da silagem de grãos de milho e a sensibilidade à pressão osmótica dessas bactérias, pode-se inferir que a atividade proteolítica é praticamente inexistente, principalmente no tratamento com inclusão de $40 \%$ de grãos de soja, onde o teor de MS verificado foi o maior entre os tratamentos.

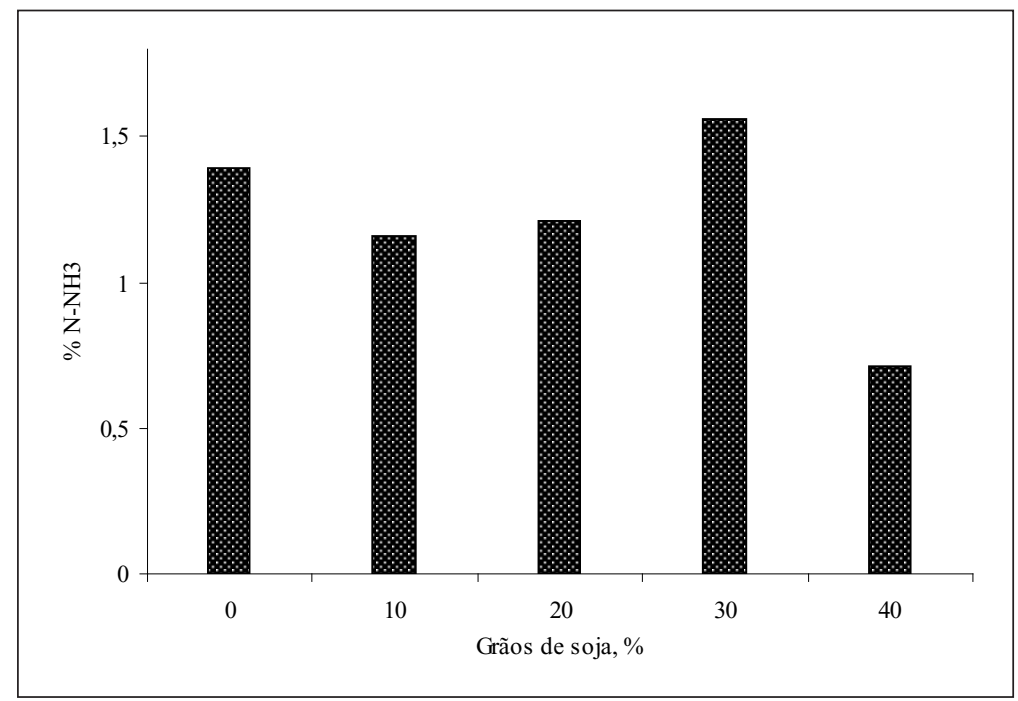

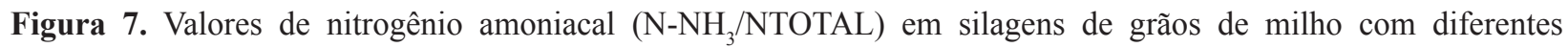
percentagens de grãos de soja.

\section{Conclusões}

É possível adicionar até $40 \%$ de grãos de soja com 73\% de MS em substituição a grãos úmidos de milho com $67 \%$ de MS, sem alterar os valores de $\mathrm{pH}$ e de $\mathrm{N}-\mathrm{NH}_{3}$ das silagens.

\section{Referências}

ASHBELL, G. Basic principles of preservation of forage, by-products and residues as silage or hay. Bet Dagan: Agricultural Research Organization, The Volcani Center. (n. 1664-E). 1995.58 p.

ASSOCIATION OF OFFICIAL ANALYTICAL CHEMISTS - AOAC. Official Methods of Analyses. 15. ed., Arlington: Virginia, USA, 1990. 1117 p. 
ÍTAVO, C. C. B. F.; MORAIS, M. G.; ÍTAVO, L. C. V.; SOUZA, A. R. D. L.; DAVY, F. C. A.; ALBERTIN, T. Z.; COSTA, C.; LEMPP, B.; JOBIM, C. C. Padrão de fermentação e composição química de silagens de grãos úmidos de milho e sorgo submetidas ou não a inoculação microbiana. Revista Brasileira de Zootecnia, Viçosa, v. 35, n. 3, p. 655-664, 2006.

JOBIM, C. C.; BRANCO, A. F.; SANTOS, G. T. Silagem de grão mole na alimentação de bovinos leiteiros. In: SIMPÓSIO GOIANO SOBRE MANEJO E NUTRIÇÃO DE BOVINOS DE CORTE E LEITE, 5., 2003, Campinas. Anais... Campinas: CBNA, 2003. p. 357-376.

JOBIM, C. C.; CECATO, U.; CANTO, M. W. Utilização de silagem de grãos de cereais na alimentação animal. In: SIMPÓSIO SOBRE PRODUÇÃO E UTILIZAÇÃO DE FORRAGENS CONSERVADAS. 2001, Maringá. Anais...Maringá: UEM, 2001, p. 146-176.

JOBIM, C. C.; REIS, R. A.; RODRIGUES, L. R. A. Avaliação da silagem de grãos úmidos de milho (Zea mays L.). Pesquisa Agropecuária Brasileira, Brasília, v. 32, n. 3, p. 311-315, 1997.

NATIONAL RESEARCH COUNCIL - NRC. Nutrient requirements of Beef Cattle. 7. ed. Washington, DC: National Academy Press, 1996. 60 p.

PASSINI, R.; SILVEIRA, A. C.; RODRIGUES, P. H. M.; CASTRO, A. L.; TITTO, E. A. L.; ARRIGONI, M. B.; COSTA, C. Digestibilidade de dietas a base de grão úmido de milho ou de sorgo ensilados. Acta Scientiarum, Maringá, v. 24, n. 4, p. 1147-1154, 2002.
PHILLIP, L. E.; FELLNER, V. Effects of bacterial inoculation of high-moisture ear corn on its aerobic stability, digestion, and utilization for growth by beef steers. Journal of Animal Science, v. 70, n. 10, p. 31783187, 1992.

REIS, W.; JOBIM, C. C.; MACEDO, F. A. F.; MARTINS, E. N.; CECATO, U.; SILVEIRA, A. Desempenho de cordeiros terminados em confinamento, consumindo silagens de milho de grãos com alta umidade ou grãos de milho hidratados em substituição aos grãos de milho seco da dieta. Revista Brasileira de Zootecnia, Viçosa, v. 30, n. 2, p. 596-603, 2001.

SANTOS, C. P.; FURTADO, C. E.; JOBIM, C. C.; FURLAN, A. C.; MURDIN, C. A.; GRAÇA, E. P. Avaliação da silagem de grãos úmidos de milho na alimentação de eqüinos em crescimento: valor nutricional e desempenho. Revista Brasileira de Zootecnia, Viçosa, v. 31, n. 3, p. 1214-1222, 2002.

UNIVERSIDADE FEDERAL DE VIÇOSA. UFV. SAEG - Sistemas de análises estatísticas e genéticas. Versão 7.1. Viçosa, MG: UFV, 1997. 150 p. (Manual do Usuário).

VAN SOEST, P. J.; ROBERTSON, J. B. Analysis of forages and fibrous foods. Ithaca: Cornell University, 1985. $202 \mathrm{p}$. 
